\title{
Zaniedbanie, brak czasu czy powszechna praktyka średniowiecznych kancelarii, czyli o brakujących inicjałach w dokumentach śląskich
}

Wprowadzanie w średniowieczu w obieg prawny dokumentów z brakującymi inicjałami bez wątpienia nie wzbudzi zdziwienia u żadnego z mediewistów. Pomimo jednak świadomości wśród badaczy powszechności tego zjawiska w literaturze poświęcono mu stosunkowo niewiele miejsca ${ }^{1}$. W Polsce jako pierwsza tematykę tę podjęła Irena Sułkowska-Kurasiowa. W swym studium poświęconym inicjałom dokumentów królewskich zwróciła uwagę na fakt, że część dyplomów opuszcza kancelarię i trafia do rąk odbiorcy bez wrysowanych inicjałów. Na tej podstawie wyciągnęła wniosek, że brak inicjału nie był elementem na tyle istotnym, by pozbawić dokument wiarygodności i mocy prawnej ${ }^{2}$. Do tematu takich „niedokończonych” dyplomów powróciła po prawie piętnastu latach Maria Koczerska w pracy poświęconej Zbigniewowi Oleśnickiemu i Kościołowi krakowskiemu. Autorka, opierając się na analizach swej poprzedniczki oraz własnych, uznała, że praktyka kancelaryjna - pozostawianie dokumentów bez wrysowanych inicjałów — świadczyć może jedynie o tym, że w skład pracowników kancelarii musieli wchodzić specjalnie powo-

${ }^{1}$ Warto w tym miejscu przywołać już dość starą pracę, w całości jednak poświęconą problematyce brakujących inicjałów dokumentowych, zob. K. von Andrian-Werburg: Die Fehlende Initiale. „Zeitschrift für bayerische Landesgeschichte“ 1992, Bd. 55, s. 51-64.

${ }^{2}$ I. Sułkowska-Kurasiowa: Inicjaty na średniowiecznych dokumentach monarszych w Polsce (do 1444 r.). W: Kultura średniowieczna i staropolska. Studia ofiarowane Aleksandrowi Gieysztorowi w pięćdziesięciolecie pracy naukowej. Warszawa 1991, s. 171-177. 
łani do ozdabiania dyplomów iluminatorzy. Wniosek swój poparła obserwacją, że inicjałów pozbawione były dokumenty mogące bez wątpienia zostać zaliczone do grona najznamienitszych. Ich ranga wskazuje tym samym na małe prawdopodobieństwo, by to ich pisarze mieli w późniejszym czasie zapełniać pozostawione przez siebie wcześniej puste miejsca ${ }^{3}$.

Przedstawione uwagi stały się dla mnie inspiracją do podjęcia własnych badań. Impulsem do ich rozpoczęcia był przede wszystkim fakt, że obie autorki skoncentrowały się tylko na dokumentach pochodzących z najwyższych kręgów władzy. Stąd też niejako zupełnie naturalne stało się pytanie, czy podobne praktyki - wprowadzanie w obieg prawny dokumentów bez inicjałów - można dostrzec także w kancelariach mniej znamienitych i bogatych wystawców. Doskonałym, jak się zdaje, materiałem do przeprowadzenia takich badań są dyplomy wystawców śląskich, tym bardziej że już wstępne spostrzeżenia wydały się interesujące ${ }^{4}$.

Śląsk od XIII wieku, w wyniku podziałów dynastycznych, powoli zmieniał się w mozaikę coraz bardziej zmniejszających się terytorialnie władztw ${ }^{5}$. Na terenie każdego z nich funkcjonowała zazwyczaj mniej lub bardziej zorganizowana kancelaria władcy. Równocześnie posługiwano się tu dokumentem miejskim, wreszcie dość sprawnie rozwijał się też dokument prywatny ${ }^{6}$. Znaczny wpływ na coraz powszechniejsze posługiwanie się dokumentem na tym terenie miała intensywna kolonizacja niemiecka w XIII wieku. Nierównomierny napływ osadników sprawił jednak, że na Śląsku można było zaobserwować swoistą dwutorowość rozwoju tego obszaru, skutkującą podziałem na bardziej skolonizowany i bogatszy Śląsk Dolny oraz biedniejszy, słabiej rozwinięty Śląsk Górny z centrum w Opolu. Owe uwarunkowania sprawiły, że współcześnie dysponujemy bardzo zróżnicowanym i ciekawym badawczo materiałem dyplomatycznym z tych terenów. Jest to też materiał niezwykle bogaty. Jedynie szacunkowo licząc, do końca XV wieku na całym Śląsku wystawiono ok. 15-16 tysięcy dokumentów? ${ }^{7}$ Napływ ludności niemieckiej odcisnął swe piętno nie tylko na

${ }^{3}$ M. Koczerska: Zbigniew Oleśnicki $i$ Kościół krakowski w czasach jego pontyfikatu (1423-1455). Warszawa 2004, s. 109.

${ }^{4}$ I. Pietrzyk: Inicjały na czternastowiecznych dokumentach książąt opolskich (Bolesława II i Bolesława III). „Średniowiecze Polskie i Powszechne” 2017, T. 9 (13), s. 96 -97.

${ }_{5}$ Przykładowo zob. Geschichte Schlesiens. Von der Urzeit bis zum Jahre 1526. Bd 1. Hrsg. L. Petry, J.J. Menzel, W. Irgang. Stuttgart 2000, passim; W. Irgang: Schlesien im Mittelalter. In: Schlesien. Geschichte, Kultur und Wirtschaft. Hrsg. W. Irgang, W. Bein, H. Neubach. Köln 1995, s. 29 i n.

${ }^{6} \mathrm{Na}$ temat procesów rozwojowych piśmienności pragmatycznej na terenie Śląska zob. przykładowo T. Jurek: Zarys dyplomatyki śląskiej w późnym średniowieczu. W: Dyplomatyka staropolska. Red. T. Jurek. Warszawa 2015, s. 499-508.

7 Omawiane zjawisko dobrze obrazuje liczba pozycji w wydanym w 2014 r. Katalogu dokumentów wrocławskiego archiwum, zob. R. Stelmach: Katalog średniowiecznych dokumentów przechowywanych w Archiwum Państwowym we Wroctawiu. Wrocław-Racibórz 2014. 
liczbie wystawianych dyplomów, lecz także na zmianach w ich wewnętrznej strukturze, przede wszystkim zaś na ich języku. Coraz powszechniejsze spisywanie dokumentów w języku niemieckim spowodowało dość szybkie wyparcie łaciny, która mniej więcej ok. połowy XIV wieku stała się językiem w zasadzie zarezerwowanym dla spraw i dyplomów związanych z Kościołem ${ }^{8}$.

Średniowieczne dokumenty śląskie nie należą do szczególnie wyrafinowanych pod względem zdobnictwa i w większości cechuje je prostota wykonania. Najczęściej stosowanym zdobieniem było wypełnianie tuszem konturu inicjału lub tylko wrysowanie zarysu inicjału bez jego wypełnienia, z prawdopodobnymi planami wypełnienia go w przyszłości ${ }^{9}$. Pomimo jednak całej swej surowości dokumenty te nie odbiegają szczególnie od standardów zdobniczych swojej epoki, powielając wzory stosowane także w innych kancelariach ${ }^{10}$.

Już pobieżna analiza śląskiego materiału dokumentowego wskazuje, że również i na tym terenie spotykamy praktykę wprowadzania w obieg prawny dyplomów z brakującymi inicjałami. Zawsze, przykładem polskiej kancelarii królewskiej czy biskupiej, był to brak pierwszej litery, mającej rozpoczynać treść całego dokumentu ${ }^{11}$. Zupełnie obcy dyplomom śląskim był natomiast zwyczaj znany z czeskiej kancelarii królewskiej, by pomijać inicjał imienia samego wystawcy dokumentu ${ }^{12}$.

Do najznamienitszych dokumentów śląskich, o wręcz fundamentalnym znaczeniu, którym nie wrysowano inicjału, zaliczyć należy te poświadczające złożenie hołdu lennego królowi czeskiemu. Co jednak niezwykle interesujące, nie wszystkie dokumenty lenne opuściły kancelarię bez swej pierwszej litery pomimo wystawienia ich $\mathrm{w}$ zbliżonym czasie ${ }^{13}$. Im właśnie ze względu na ich rangę oraz

Katalog ten kończy pozycja nr 17214. Na liczbę tę składają się w przeważającej większości dokumenty wystawców śląskich. Wyraźną dysproporcję wobec opisywanego Katalogu pokazują regesty dokumentów z archiwów górnośląskich, zob. Regesty dokumentów przechowywanych na Górnym Śląsku. T. 1-3. Red. A. Barciak, K. Müller. Wrocław-Opawa-Opole-Katowice 2004-2017 — tu autorzy wyliczają niewiele ponad tysiąc pozycji, włączając w to także niewielką liczbę dokumentów wystawców spoza terenu Śląska.

${ }^{8}$ W ujęciu syntetycznym na ten temat zob. T. Jurek: Zarys dyplomatyki..., s 502.

9 Średniowieczne dokumenty wystawców śląskich nie doczekały się jeszcze odrębnego studium paleograficznego, dlatego też wciąż nieodzowną praktyką pozostaje powoływanie się na załączniki prac dyplomatycznych, gdzie zamieszcza się fotografie przynajmniej części badanych dokumentów.

${ }^{10}$ Na pojawianie się podobnych zdobień w dokumentach różnych wystawców zwrócił już uwagę I. Hlaváček, zob. Tenże: Zu den graphischen Elementen im böhmischen Urkundenwesen der vorhussitischen Zeit (bis 1419). In: Graphische Symbole in mittelalterlichen Urkunden. Beiträge zur diplomatischen Semiotik. Hrsg. P. Rück. Sigmaringen 1996, s. 576-577.

${ }^{11}$ I. Sułkowska-Kurasiowa: Inicjały..., s. 177; M. Koczerska: Zbigniew Oleśnicki..., s. 109.

12 I. Hlaváček: Zu den graphischen Elementen..., s. 576.

13 Spośród wszystkich śląskich dokumentów lennych znamy dwa, w których brakuje inicjału. Są to: dokumenty Bolesława II, księcia opolskiego, z 1327 r. (Národní archiv Praha (dalej: NA Praha), Archiv České Koruny, inv. č. 124, druk w: LBS, Bd. 2, s. 304, nr 6) oraz 
specyfikę postanowiłam poświęcić odrębne studium, wydzielając je tym samym $\mathrm{z}$ analizowanego zbioru. Przemawia za tym również fakt, że są one uznawane za wytwór czeskiej kancelarii królewskiej, nie zaś rodzimych kancelarii śląskich ${ }^{14}$.

Odkładając kwestię dokumentów lennych, należy zauważyć, że przeprowadzona kwerenda pozwoliła na skatalogowanie 64 zachowanych w oryginale dyplomów, których autentyczność nie budzi i nie budziła dotychczas żadnych wątpliwości badaczy ${ }^{15}$. Wskazana liczba nie jest zapewne ostateczna, a dalsze badania umożliwią powiększenie prezentowanego zbioru tak, by móc w pełni oszacować skalę omawianego zjawiska. Warto w tym miejscu po raz kolejny przytoczyć ustalenia M. Koczerskiej, która wykazała, że na 239 datowanych, wystawionych przez biskupa Oleśnickiego dokumentów jedynie sześć pozostawiono bez wrysowanych inicjałów ${ }^{16}$. Stanowi to więc niewielki odsetek. Można przypuszczać, że mniej więcej podobne proporcje spotkamy na sąsiednim Śląsku. Samo zresztą zwiększenie liczby dokumentów nie wpłynie znacząco, jak się wydaje, na wnioski końcowe niniejszych rozważań.

Najwcześniejszy ze śląskich dyplomów bez inicjału datowany jest na 1251 rok. To spisany w języku łacińskim dyplom, którego wystawcą był książę Henryk III wrocławski ${ }^{17}$. Czas wystawienia owego dokumentu - co warte jest odnotowania - zbiega się dokładnie z czasem pojawienia się dokumentów bezinicjałowych także w kancelariach wystawców niemieckich ${ }^{18}$. Najpóźniejszy z odnalezionych dokumentów to niemieckojęzyczny dyplom z 1458 roku, który

Bolesława Pierworodnego, księcia niemodlińskiego, z 1327 r. (NA Praha, Archiv České Koruny, inv. č. 118, druk w: LBS, Bd. 2, s. 303, nr 5). Pobieżne badania pozostałych dokumentów lennych wskazują, że część z nich, współcześnie posiadająca inicjały, pierwotnie, opuszczając kancelarię, ich nie posiadała; jedynie część ze wzmiankowanych dokumentów została przed oddaniem ich w ręce odbiorcy w pełni „dokończona”.

${ }^{14}$ P. Bar: Lenní listiny z let 1271-1348 a integracje slezských vévodů do svazku zemí Koruny české. V: Slezsko - země Koruny české. Historie a kultura 1300-1740. Díl. A. Edd. H. Dánová, J. Klípa, I. Stolárová. Praha 2008, s. 107; R. Antonín: Jan Lucemburský a slezská knižata v letech 1327-1329. „Slezský sborník. Acta Silesiaca Opava“ 2010, roč. 108, č. 1-2, s. 12-14. Wymienione prace odnoszą się przede wszystkim do kwestii politycznych, marginalnie podejmując analizę paleograficzną, nakierowaną jedynie na wskazanie pochodzenia owych dokumentów.

${ }^{15}$ Przeprowadzona kwerenda objęła zasoby Archiwum Państwowego we Wrocławiu, Archiwum Państwowego w Opolu, a także Archiwum w Opawie. Na marginesie warto dodać, że braki inicjałów zdarzają się też w dokumentach powszechnie budzących wątpliwości co do ich autentyczności. Samoistnie i nieco przewrotnie nasuwa się tu przypuszczenie, że niewrysowanie do fałszowanego dyplomu inicjału mogło zwyczajnie stanowić formę jego uwiarygodnienia. Czy ta dość odważna teza znajdzie jakiekolwiek potwierdzenie w badaniach — zobaczymy, myślę jednak, że na pewno może wskazywać na powszechność zjawiska, jakim było „niedokańczanie” dokumentów i wprowadzanie ich w prawny obieg.

${ }^{16}$ M. Koczerska: Zbigniew Oleśnicki..., s. 109, 122.

17 Dokument, o rozbudowanym formularzu, dotyczy zwolnienia od obciążeń oraz nadania prawa do lokowania na prawie niemieckim magistrowi Mikołajowi, zob. SUb, Bd. 3, nr 18.

${ }^{18}$ K. von Andrian-Werburg: Die Fehlende Initiale..., s. 51. 
wystawiła księżna legnicka Jadwiga ${ }^{19}$. W tym wypadku badania na niemieckim materiale dokumentowym wydłużają nieco czas występowania dokumentów bezinicjałowych, bo aż do schyłku wieku $\mathrm{XV}^{20}$. Badania te nie podają jednak, czy po tym okresie stosowana praktyka zupełnie zniknęła z kancelarii, czy też była kontynuowana $\mathrm{w}$ jakimś zakresie także $\mathrm{w}$ wiekach późniejszych ${ }^{21}$.

Na Śląsku dokumenty bez inicjałów odnajdujemy pośród dyplomów reprezentujących szerokie kręgi wystawców. Są tu dokumenty zarówno wystawców świeckich, jak i duchownych. Zdecydowaną większość stanowią dokumenty książęce ${ }^{22}$ oraz biskupie ${ }^{23}$. Reprezentowane są też dokumenty wyższego duchowieństwa $^{24}$ oraz pojedyncze dyplomy przedstawicieli władz miejskich ${ }^{25}$. Wreszcie odnaleźć można tu również dokumenty osób prywatnych ${ }^{26}$.

Największą grupą omawianych dokumentów są dyplomy trzynastowieczne, które stanowią ponad połowę całego zbioru. Dokumenty czternastowieczne to ok. $40 \%$, pozostałe zaś $10 \%$ to dyplomy wystawione w wieku $\mathrm{XV}^{27}$. W prezentowanym zbiorze - co godne odnotowania — zdecydowanie dominują dokumenty reprezentujące dyktat wystawcy. Jedynie wobec kilku rozpoznaje się nieokreśloną proweniencję lub dyktat odbiorcy, z tym że zawsze był to odbiorca lokalny ${ }^{28}$.

19 Dokument rozpoczyna się inwokacją i dotyczy potwierdzenia przez księżną sprzedaży czynszu przez Bernarda Busewoi z Nowego Dworu Annie Slewitczin, zob. AP Wrocław, Rep. 3, sygn. 748a; R. Stelmach: Katalog..., nr 12080.

${ }^{20}$ K. von Andrian-Werburg: Die Fehlende Initiale..., s. 51.

${ }^{21}$ Przedstawiane w niniejszym artykule zjawisko bez wątpienia nie należy do najbardziej ważkich problemów badawczych z pogranicza paleografii i dyplomatyki, niemniej jednak wydaje się niezwykle interesujące i słabo rozpoznane. Szczególnie owocne mogłyby się okazać zwłaszcza badania porównawcze na możliwie szerokim, europejskim materiale dokumentowym.

${ }^{22}$ Wśród nich dominują dokumenty wystawione przez książąt panujących na Dolnym Śląsku. Istnieją 23 takie dyplomy. Zdecydowanie mniej jest dokumentów książąt górnośląskich. Tych jest jedynie sześć.

${ }^{23} \mathrm{Z}$ całego okresu znamy 25 takich dokumentów.

${ }^{24} \mathrm{~W}$ całym zbiorze jest pięć takich dokumentów, których wystawcą jest kapituła wrocławska, zob. SUb, Bd. 6, nr 21, 277, 278, 279, 394

${ }^{25}$ Należą do nich dokumenty: wójta i rady miejskiej Głogowa (zob. tamże, nr 45) oraz burmistrza i rajców nyskich (zob. AP Opole, Akta miasta Nysy, nr 93).

${ }^{26}$ Są to trzy dokumenty: braci Kietliczów - Henryka i jego młodszego brata — z 1290 r., sprzedających folwark koło Żagania Jakubowi, mieszczaninowi żagańskiemu, zob. SUb, Bd. 5, nr 485; Czcibora z Czesławic z synami z 1306 r., zastawiającego dwa łany cystersom henrykowskim, zob. AP Wrocław, Rep. 84, nr 45; oraz Piotra Rosslau z 1458 r., potwierdzającego sprzedaż przez Macieja Jackischa czynszu na rzecz altarysty kościoła parafialnego w Paczkowie, zob. AP Opole, Akta miasta Paczkowa, nr 146.

27 Wpływ na takie właśnie proporcje może mieć bardzo dobre rozpoznanie i opracowanie śląskiego materiału dokumentowego do końca XIII w. Dużo gorzej przedstawia się to dla wieków późniejszych, gdzie niejednokrotnie bardzo rozproszony materiał wymusza poruszanie się nieco ,po omacku”.

${ }^{28}$ Jest to zaledwie sześć dokumentów: biskupa wrocławskiego Tomasza z 1258 r., w którym ustanawia on dziesięcinę na rzecz klasztoru św. Wincentego we Wrocławiu, zob. SUb, Bd. 3, nr 261; księcia opolskiego Władysława I dla klasztoru w Czarnowąsach z 1260 r. — dokument ten 
Warto zwrócić uwagę na język owych dyplomów. W analizowanym zespole obecne są zarówno dokumenty spisane w języku łacińskim, jak i niemieckim. Dokumenty w języku niemieckim pojawiają się jednak bardzo późno, bo dopiero w wieku XV. Dzieje się tak pomimo faktu, że język ten staje się powszechny na Śląsku już od połowy wieku XIV. Są zaledwie cztery takie dyplomy. Najstarszy pochodzi z 1413 roku, a jego wystawcą był książę opolski Bolesław IV (fot. 1), kolejne dwa datowane są na 1428 rok - wystawione przez właściciela wsi Pomianów Dolny Piotra Rosslau ${ }^{29}$ (fot. 2 i 11), najpóźniejszy zaś, z 1458 ro$\mathrm{ku}$, to wspomniany już dokument Jadwigi, księżnej legnickiej (fot. 3).

Najczęściej w dyplomach brakuje litery „I”, która w założeniu miała inicjować inwokację - formułę charakterystyczną dla dokumentów o rozszerzonym formularzu. Dokumenty śląskie nie odbiegają tym samym od praktyki obserwowanej także w dyplomach polskich wystawców ${ }^{30}$. W przeciwieństwie jednak do tych dokumentów na Śląsku nie było to absolutną regułą. Brak inicjału „I” zauważamy również w niemieckojęzycznych dokumentach o skróconym formularzu, rozpoczynających się intytulacją z zaimkiem „Ich”31 (fot. 2 i 11). W pojedynczych jedynie dyplomach brakującymi inicjałami były litery: „A"32 (fot. 4) oraz „," ${ }^{\prime 33}$ (fot. 5).

Nieporuszaną dotąd kwestię stanowi treść owych dokumentów. W przypadku Śląska były to sprawy dotyczące szeroko rozumianego przeniesienia

prezentuje nietypowy formularz, rozpoczynający się datacją; Konrada I, księcia śląskiego, z 1261 r., nadającego wolności na rzecz kolegiaty głogowskiej, zob. tamże, nr 353; Henryka i jego młodszego brata Kietliczów z 1290 r., sprzedających folwark koło Żagania Jakubowi, mieszczaninowi żagańskiemu, zob. SUb, Bd. 5, nr 485; wójta, ławników oraz rajców głogowskich z 1292 r., zawierających ugodę i zobowiązujących się do rocznej dostawy łoju na rzecz kolegiaty głogowskiej - datacja tego dokumentu rozpoczyna się od słów: „Actum et datum in Glogovia in refectorio fratrum Predicatorum", zob. SUb, Bd. 6, nr 45; Bolka, księcia lwóweckiego, z 1293 r., potwierdzający nadanie na rzecz klasztoru w Kamieńcu przez rycerza Jana, zob. tamże, nr 95.

${ }^{29}$ Wieś położona na Dolnym Śląsku, niedaleko Paczkowa.

${ }^{30}$ Praktyki tego typu znajdujemy zarówno w kancelarii królów polskich, jak i w kancelarii biskupa Oleśnickiego, zob. I. Sułkowska-Kurasiowa: Inicjały..., s. 172_173; M. Koczerska: Zbigniew Oleśnicki..., s. 109.

${ }^{31}$ Mowa tu o wspominanym już dokumencie z 1428 r. niejakiego Piotra Rosslau, dziedzica wsi Pomianów Dolny, dotyczącym sprzedaży czynszu na rzecz altarysty w kościele parafialnym w Paczkowie, zob. AP Opole, Akta miasta Paczkowa, nr 49; Regesty dokumentów..., T. 2, s. 151, nr 388 .

${ }^{32}$ Inicjał ten rozpoczyna dokument z 1260 r. o dość nietypowym formularzu zaczynającym się datacją. Dotyczy on potwierdzenia przywileju oraz nadania na rzecz czarnowąskich norbertanek przez księcia Władysława opolskiego, por. AP Wrocław, Rep. 71, nr 5a; SUb, Bd. 3, nr 340. Na temat tego dokumentu zob. M.L. Wójcik: Dokumenty i kancelarie ksiażąt opolsko-raciborskich do początków XIV wieku. Wrocław 1999, s. 120.

33 To kolejny dokument o nieczęstym formularzu rozpoczynającym się arengą. Wystawiony został przez księcia Mikołaja I opawskiego w 1284 r., dotyczył potwierdzenia dotychczasowych praw i przywilejów miastu Opawa, zob. Statní okresní archiv Opava, AmOpava, i.č. 2, sign.I/7; SUb, Bd. 5, nr 83. 
praw własności, jak chociażby sprzedaży majątków. Znajdujemy tu też potwierdzenia różnorodnych przywilejów oraz posiadanych już dóbr. Pod względem więc treści dokumenty te w żaden sposób nie odróżniały się od tych, które posiadały inicjały. Zobrazować te słowa może zaprezentowane tu zestawienie dyplomów zawierających inicjały z takimi, które ich nie posiadają:

1. Dokumenty biskupa wrocławskiego Tomasza I (fot. 6):

— bez inicjału, z 1261 roku — w którym biskup nadaje klasztorowi Augustianów w Nowogrodzie Bobrzańskim dziesięciny z Brzeźnicy ${ }^{34}$;

— z inicjałem, z 1268 roku — w którym biskup zakłada dziesiątą prebendę kolegiaty głogowskiej, przyznaje jej dziesięciny z Racławic Sląskich oraz nadaje ją Tomaszowi, kanonikowi wrocławskiemu ${ }^{35}$.

Oba dokumenty zostały sporządzone przez tego samego pisarza ${ }^{36}$.

2. Dokumenty księcia opolskiego Bolesława I (fot. 7 i 8):

— bez inicjału, z 1297 roku — w którym książę zezwala swemu prokuratorowi Gierko na budowę domu nad Odrą w Opolu oraz uwalnia go od wszelkich opłat ${ }^{37}$;

— z inicjałem, z 1301 roku — w którym w obecności księcia rozstrzygnięty został spór o las między opatem lubiąskim a Adykiem z Pisarzowic 38 ;

— z inicjałem, z 1304 roku — w którym książę Bolesław nadaje Boguszowi zwanemu Stobrawa sołectwo z przyległościami w Popielowie ${ }^{39}$.

Dokumenty zostały spisane jedną ręką ${ }^{40}$.

3. Dokumenty księcia opawskiego Mikołaja I (fot. 9):

— bez inicjału, z 1284 roku - w którym książę zawiera ugodę z mieszczanami opawskimi i zobowiązuje się do zachowania ich dotychczasowych $\operatorname{praw}^{41}$;

— z inicjałem, z 1281 roku — w którym książę daruje las miastu Karniów ${ }^{42}$.

Oba dokumenty spisała ta sama osoba ${ }^{43}$.

${ }^{34}$ AP Wrocław, Rep. 116, nr 13; SUb, Bd. 3, nr 358; R. Stelmach: Katalog..., nr 430.

35 AP Wrocław, Rep. 107, nr 2; SUb, Bd. 4, nr 55; R. Stelmach: Katalog..., nr 508.

${ }^{36}$ R. Żerelik: Kancelaria biskupów wrocławskich do 1301 roku. Wrocław 1991, s. 170.

37 AP Wrocław, Rep. 91, nr 124; SUb, Bd. 4, nr 329; R. Stelmach: Katalog..., nr 828.

38 AP Wrocław, Rep. 91, nr 133; R. Stelmach: Katalog..., nr 889.

39 AP Wrocław, Rep. 4f, nr 55b; R. Stelmach: Katalog..., nr 935.

${ }^{40}$ M.L. Wójcik: Dokumenty..., s. 300-301.

${ }^{41}$ Státní okresní archiv Opava, AmOpava, i.č. 2, sign.I/7; SUb, Bd. 5, nr 83; Regesty dokumentów..., T. 1, nr 9.

${ }^{42}$ Zemský archiv v Opavě, Jan Spatzier, inv. č. 26; Regesty dokumentów..., T. 1, nr 8.

${ }^{43}$ Informacja podana na podstawie badań porównawczych pisma obu dokumentów, które przeprowadziłam na potrzeby niniejszego artykułu. 
4. Dokumenty księcia bytomskiego Siemowita ${ }^{44}$ (fot. 10):

— bez inicjału, z 1316 roku - w którym książę wydaje orzeczenie na niekorzyść Pawła, mieszczanina bytomskiego, oskarżającego Jana, prepozyta kościoła św. Małgorzaty w Bytomiu, o odprowadzanie wody $\mathrm{z}$ młyna do stawu rybnego, co miało spowodować unieruchomienie tego młyna ${ }^{45}$;

— z inicjałem, z 1311 roku — w którym książę potwierdza nadanie Jaśka Slocousta wsi Miłowice na rzecz klasztoru Cystersów w Rudach ${ }^{46}$.

Oba dokumenty napisała ta sama osoba ${ }^{47}$.

5. Dokumenty właściciela wsi Pomianów Dolny Piotra Rosslau (fot. 11):

— bez inicjału, z 15 października 1428 roku — w którym wystawca poświadcza, że jego poddany Maciej sprzedał 5 grzywien groszy praskich i $1 / 2$ grzywny czynszu ze swej zagrody oraz 12 i $1 \frac{1}{2}$ pręta pola Piotrowi Kesemanowi, altaryście w kościele parafialnym w Paczkowie ${ }^{48}$;

— z inicjałem, z 15 października 1428 roku — w którym wystawca poświadcza, że jego poddany Dytryk sprzedał 3 grzywny czynszu oraz 3 pręty pola wspomnianemu w poprzednim dokumencie Piotrowi Kesemanowi, altaryście w kościele parafialnym w Paczkowie ${ }^{49}$. Dokument ten zwraca uwagę ozdobnie wykonanym inicjałem.

Oba dokumenty wystawione przez Piotra Rosslau sporządził ten sam pisarz $^{50}$.

6. Dokumenty biskupa wrocławskiego Przecława (fot. 12):

— bez inicjału, z 17 marca 1351 roku — w którym biskup poświadcza, że Jan Scharfenbeg i Kunco Byschofshem za 25 grzywien zrezygnowali na rzecz miasta ze wszystkich praw do $\operatorname{lasu}^{51}$;

— z inicjałem, z 4 marca 1351 roku — w którym biskup stwierdza, że mieszczanin nyski Piotr Fulschussil sprzedał Meczce, wdowie po Janie Opolerze z Nysy, 3/4 oraz 2 i 1/2 pręta roli koło Nysy ${ }^{52}$.

Oba dokumenty spisała ta sama osoba ${ }^{53}$.

${ }^{44}$ Władca ten był mało znaczącym księciem i niezbyt wiele o nim wiadomo, zob. Książęta i księżne Górnego Śląska. Red. A. Barciak. Katowice 1995, s. 108-109.

${ }^{45}$ AP Wrocław, Rep. 67, nr 159; R. Stelmach: Katalog..., nr 1255.

${ }^{46}$ AP Wrocław, Rep. 114, nr 18; R. Stelmach: Katalog..., nr 1107.

${ }^{47}$ Informacja podana na podstawie badań porównawczych pisma obu dokumentów, które przeprowadziłam na potrzeby niniejszego artykułu.

48 AP Opole, Akta miasta Paczkowa, nr 146; Regesty dokumentów..., T. 2, nr 387.

49 AP Opole, Akta miasta Paczkowa, nr 147; Regesty dokumentów..., T. 2, nr 388.

${ }^{50}$ Informacja podana na podstawie badań porównawczych pisma obu dokumentów, które przeprowadziłam na potrzeby niniejszego artykułu.

${ }_{51}$ AP Opole, Akta miasta Nysy, nr 20; Regesty dokumentów..., T. 1, nr 62.

52 AP Opole, Akta miasta Nysy, nr 19; Regesty dokumentów..., T. 1, nr 61.

${ }^{53}$ Informacja podana na podstawie badań porównawczych pisma obu dokumentów, które przeprowadziłam na potrzeby niniejszego artykułu. 
7. Ponownie dokumenty biskupa wrocławskiego Przecława (fot. 13):

— bez inicjału, z 1368 roku - w którym biskup stwierdza, że Formoza, wdowa po Polczku, wraz z synami przekazała Marcinowi, mieszczaninowi nyskiemu, i jego żonie sołectwo w Świętowie Polskim w zamian za sołectwo w Lipnikach i 360 grzywien $^{54}$;

— z inicjałem, z 1366 roku — w którym biskup zatwierdza fundację altarii przez mieszczanina nyskiego Ekkeharda i jego żonę z uposażeniem w postaci czynszu z 10 łanów w Starym Paczkowie kupionym od Kunegundy, wdowy po Piotrze. Po śmierci fundatorów prawo patronatu nad altarią miało przejść na Klarę, bratanicę Elżbiety5;

— z inicjałem, z 1369 roku — w którym Przecław stwierdza, że ksiądz Piotr sprzedał nyskiemu altaryście Henrykowi z Brzegu 1 grzywnę czynszu ze swoich dóbr w Nowakach ${ }^{56}$.

W wypadku tych dokumentów nie ma absolutnej pewności, że spisano je tą samą ręką.

8. Dokumenty biskupa wrocławskiego Konrada (fot. 14):

- bez inicjału, z 30 sierpnia 1420 roku - w którym Konrad, biskup wrocławski, książę śląski i pan na Prudniku, widymuje wcześniejsze dokumenty dotyczące Prudnika ${ }^{57}$;

- bez inicjału, z 14 marca 1420 roku - w którym biskup Konrad potwierdza sprzedaż 2 i $1 \frac{1}{2}$ łana mieszczaninowi paczkowskiemu, odbytą przed Mikołajem Pogorzelą, starostą otmuchowskim. W dokumencie wymienieni są także chłopi uprawiający tę ziemię, napisano też, że na wspomnianych dobrach ciąży opłata $\mathrm{z}$ tytułu służby konnej ${ }^{58}$;

— z inicjałem, z 4 czerwca 1420 roku — w którym biskup za zgodą kapituły wrocławskiej nadaje miastu Paczków las koło wsi Gościce ${ }^{59}$;

— z inicjałem, z 4 lipca 1419 roku — gdzie biskup potwierdza, że Piotr Sporer jest posiadaczem dóbr, które kupił niegdyś od Macieja ze Świętowa Polskiego, co wymieniony Piotr oświadczył przed prokuratorem otmuchowskim Mikołajem $^{60}$.

Wszystkie wzmiankowane dokumenty spisał jeden pisarz ${ }^{61}$.

${ }_{54}$ AP Opole, Akta miasta Nysy, nr 36; Regesty dokumentów..., T. 1, nr 100.

55 AP Opole, Akta miasta Nysy, nr 30; Regesty dokumentów..., T. 1, nr 90.

56 AP Opole, Akta miasta Nysy, nr 38; Regesty dokumentów..., T. 1, nr 104.

57 AP Opole, Akta miasta Prudnika, nr 9; Regesty dokumentów..., T. 2, nr 274.

58 AP Opole, Akta miasta Paczkowa, nr 137; Regesty dokumentów..., T. 2, nr 264.

59 AP Opole, Akta miasta Paczkowa, nr 1; Regesty dokumentów..., T. 2, nr 270.

60 AP Opole, Akta miasta Nysy, nr 130; Regesty dokumentów..., T. 2, nr 254.

${ }^{61}$ Informacja podana na podstawie badań porównawczych pisma obu dokumentów, które przeprowadziłam na potrzeby niniejszego artykułu. 


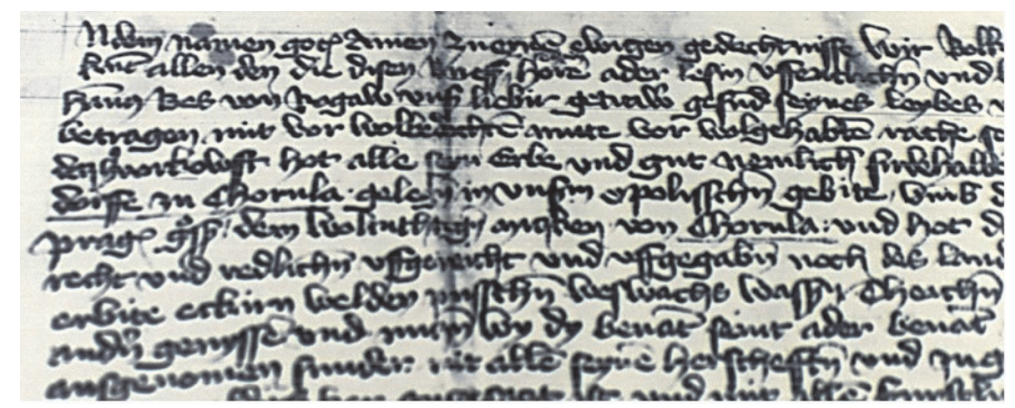

Fot. 1. Dokument księcia opolskiego Bolesława IV z 1413 roku.

AP Wrocław, Rep. 4f, sygn. 13

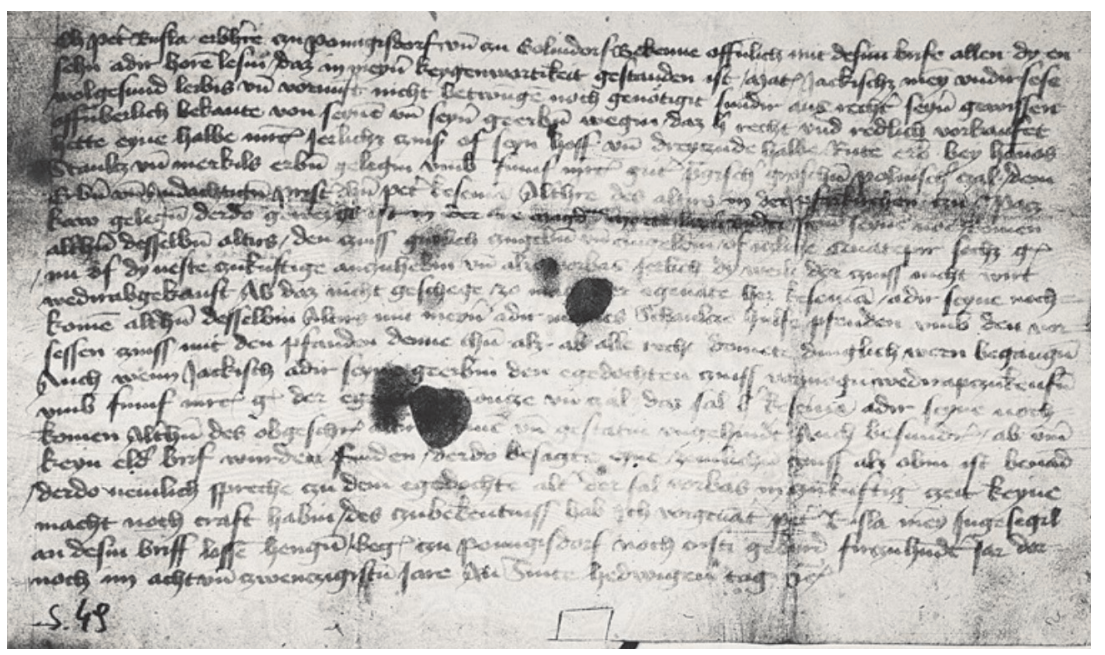

Fot. 2. Dokument Piotra Rosslau, dziedzica wsi Pomianów Wielki, z 1428 roku. AP Opole, Akta miasta Paczkowa, nr 146

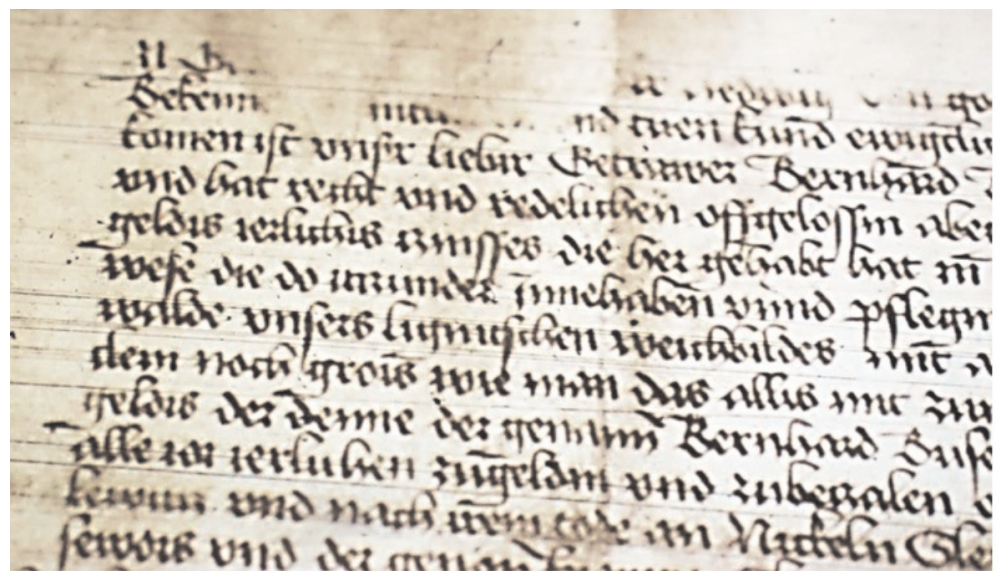

Fot. 3. Dokument Jadwigi, księżnej legnickiej, z 1458 roku. AP Wrocław, Rep. 3, sygn. 748a 


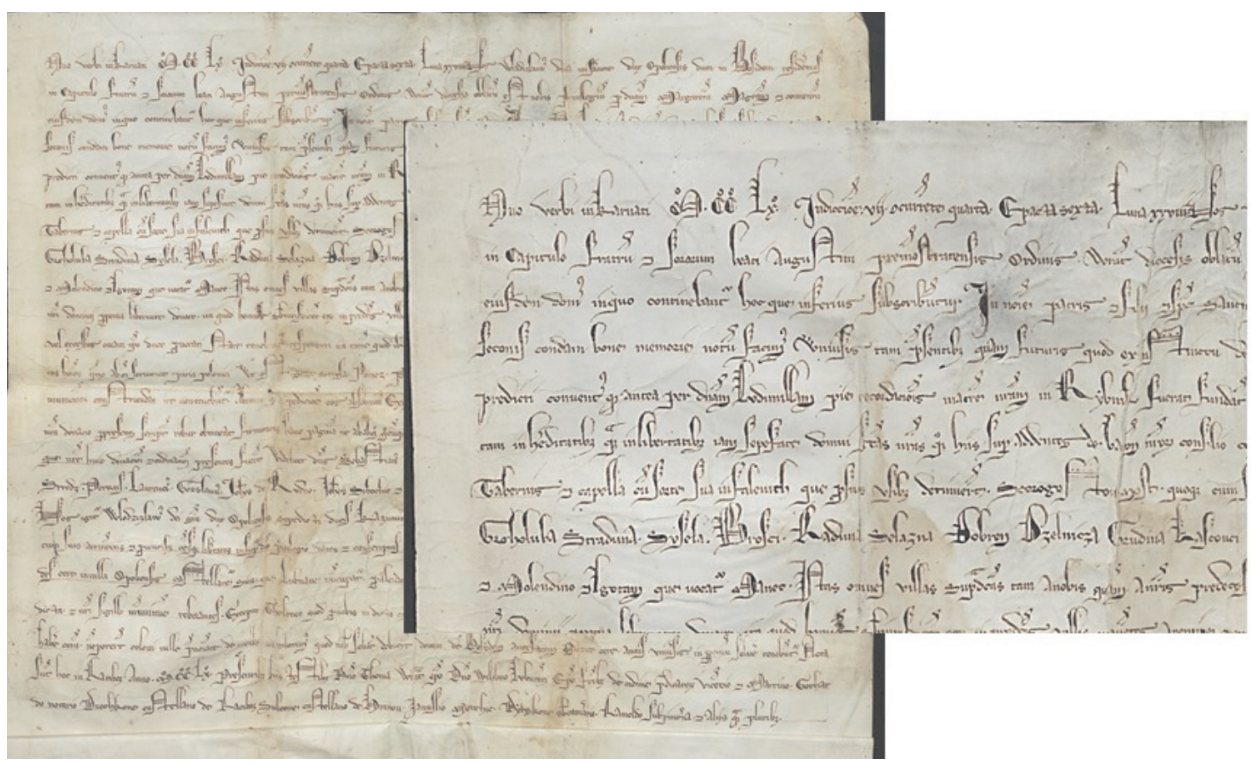

Fot. 4. Dokument księcia Władysława opolskiego z 1260 roku.

AP Wrocław, Rep. 71, nr 5a

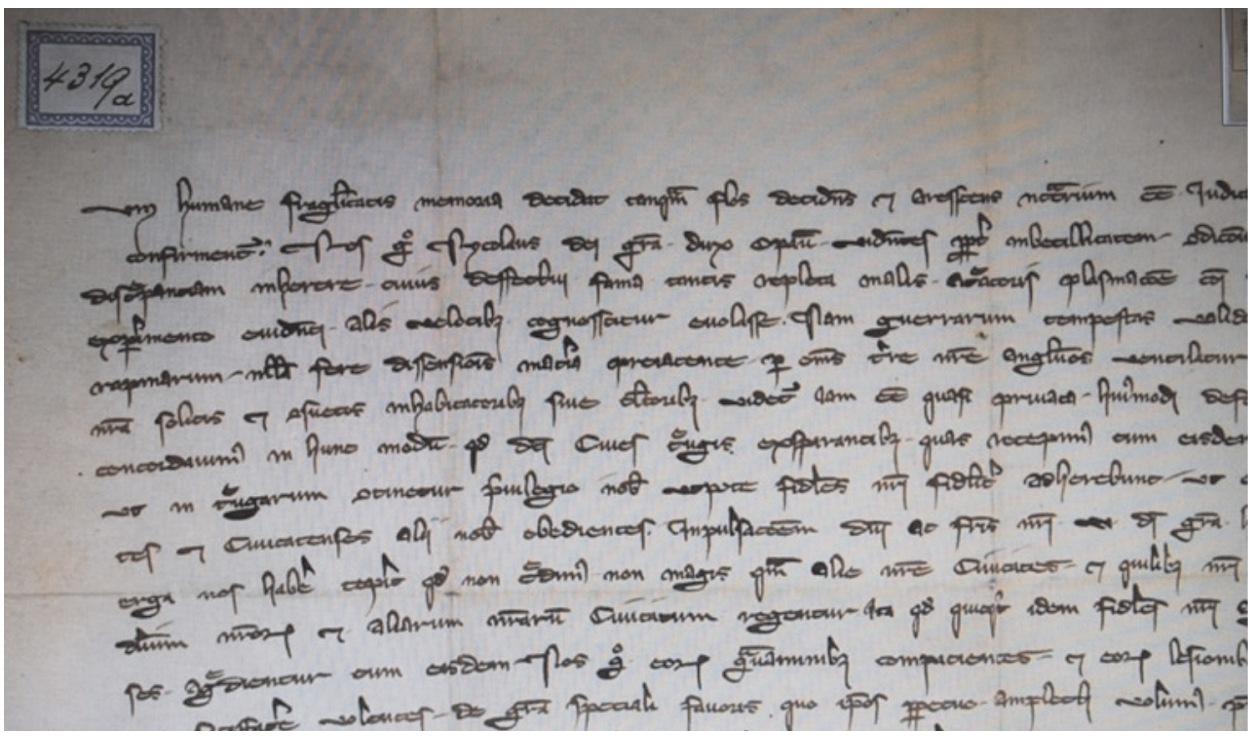

Fot. 5. Dokument księcia Mikołaja I opawskiego z 1284 roku. Statní okresní archiv Opava, AmOpava, i.č. 2, sign.I/7 


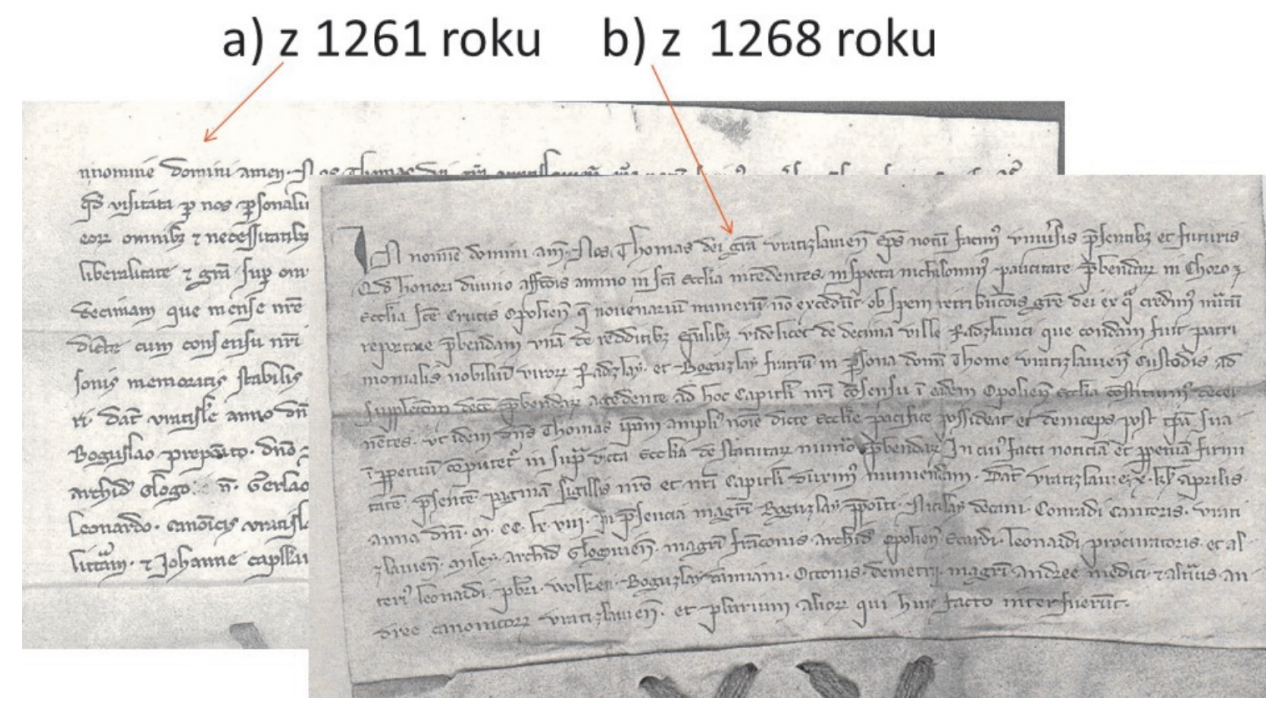

Fot. 6. Dokumenty biskupa wrocławskiego Tomasza I: a) z 1261 roku.

AP Wrocław, Rep. 116, nr 13; b) z 1268 roku. AP Wrocław, Rep. 107, nr 2

\section{$\begin{array}{lll}\text { a) z } 1297 \text { roku } & \text { b) z } 1301 \text { roku }\end{array}$}

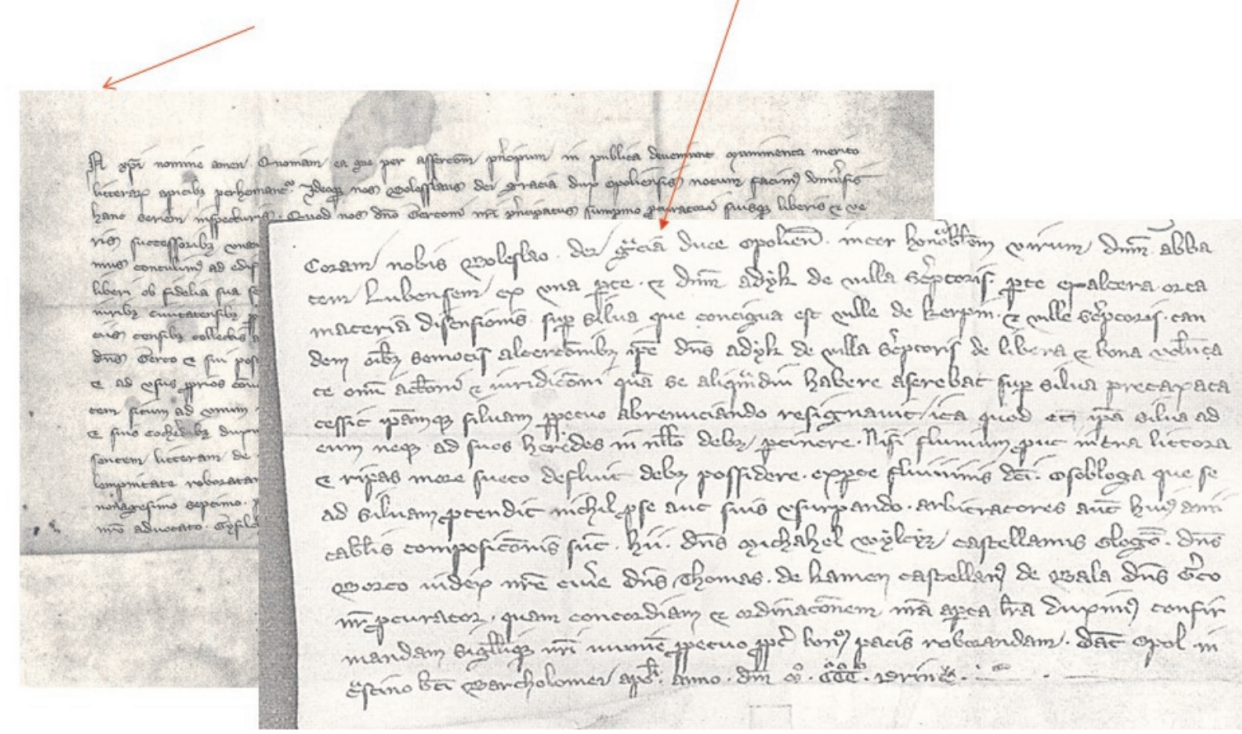

Fot. 7. Dokumenty księcia Bolesława I opolskiego: a) z 1297 roku.

AP Wrocław, Rep. 91, nr 124; b) z 1301 roku. AP Wrocław, Rep. 91, nr 133 


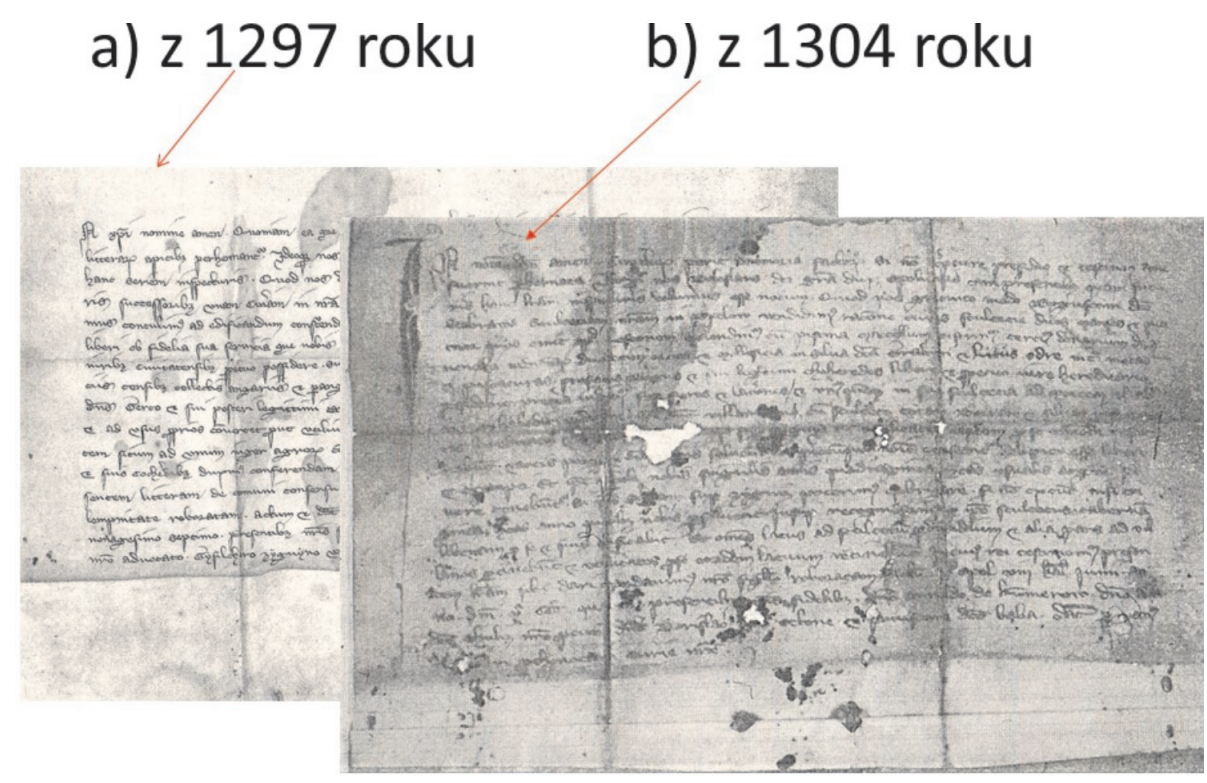

Fot. 8. Dokumenty księcia Bolesława I opolskiego: a) z 1297 roku.

AP Wrocław, Rep. 91, nr 124; b) z 1304 roku. AP Wrocław, Rep. 4f, nr 55b

\section{a) z 1284 roku \\ b) z 1281 roku}

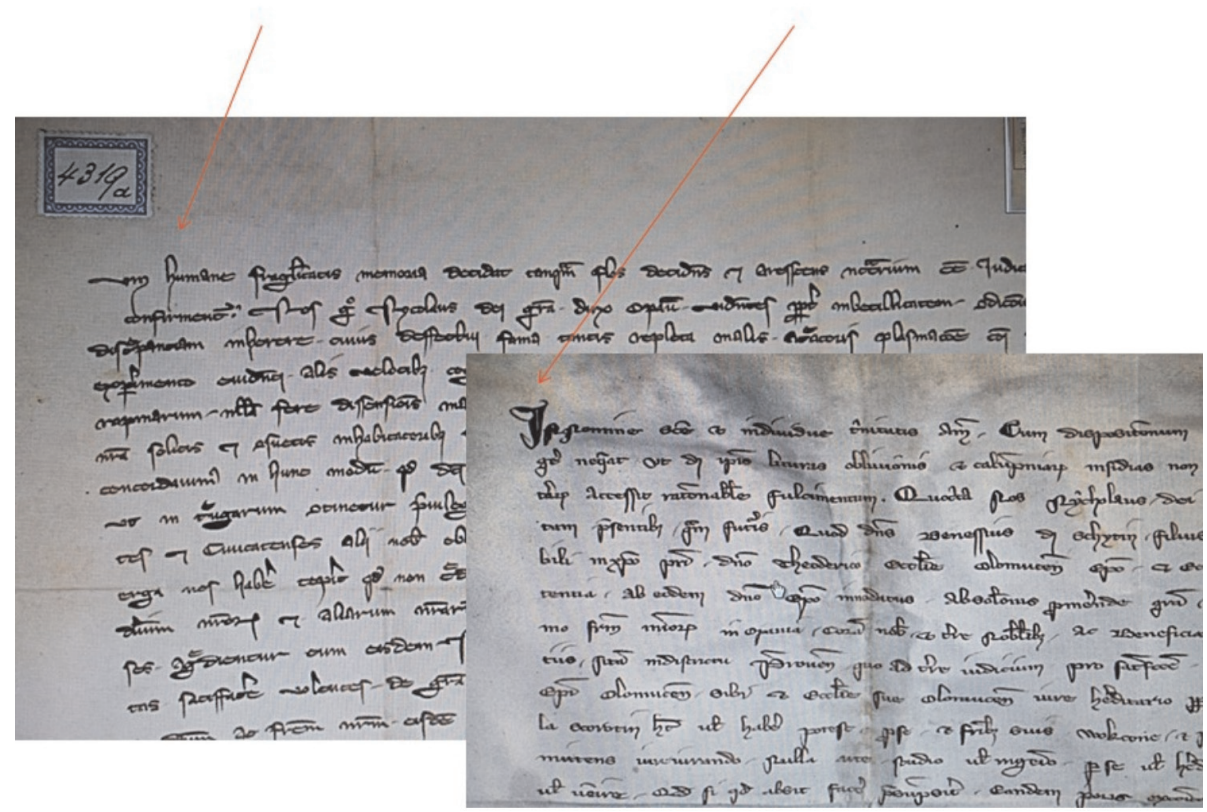

Fot. 9. Dokumenty księcia Mikołaja I opawskiego: a) z 1284 roku. Statní okresní archiv Opava, AmOpava, i.č. 2, sign.I/7; b) z 1281 roku. Zemský archiv v Opavě, Jan Spatzier, inv. č. 26 


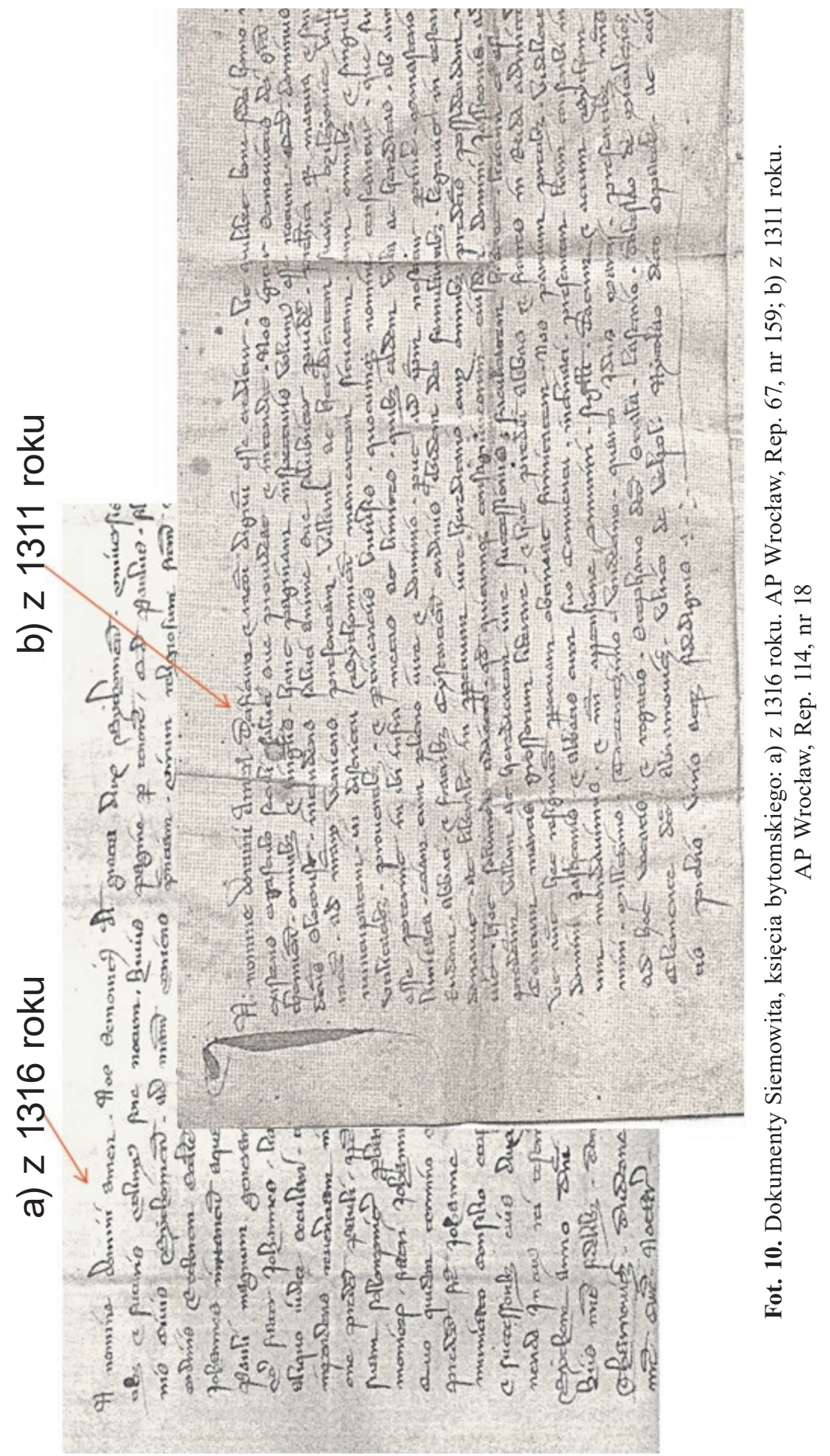


a) z 15 października 1428 roku

b) z 15 października 1428 roku

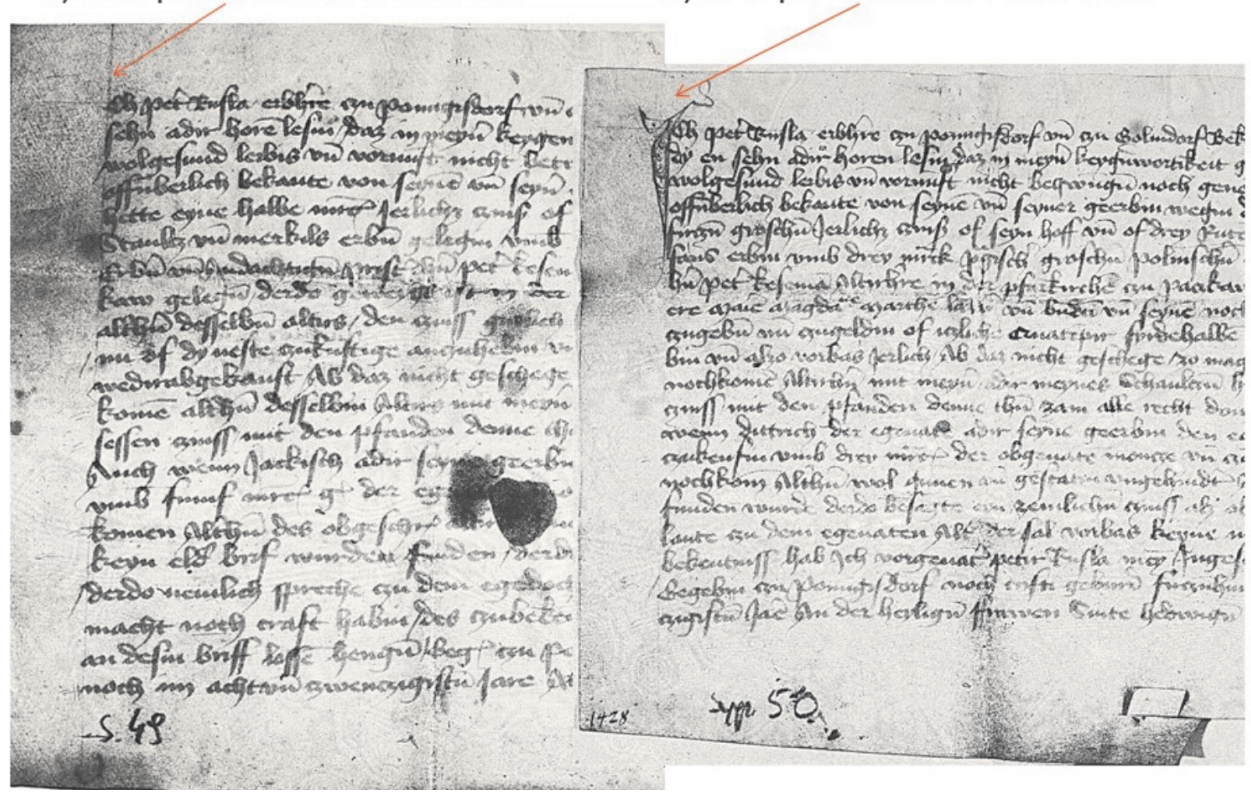

Fot. 11. Dokumenty Piotra Rosslau, dziedzica wsi Pomianów Wielki:

a) z 15 października 1428 roku. AP Opole, Akta miasta Paczkowa, nr 146;

b) z 15 października 1428 roku. AP Opole, Akta miasta Paczkowa, nr 147
a) z 17 marca 1351 roku
b) z 4 marca 1351 roku
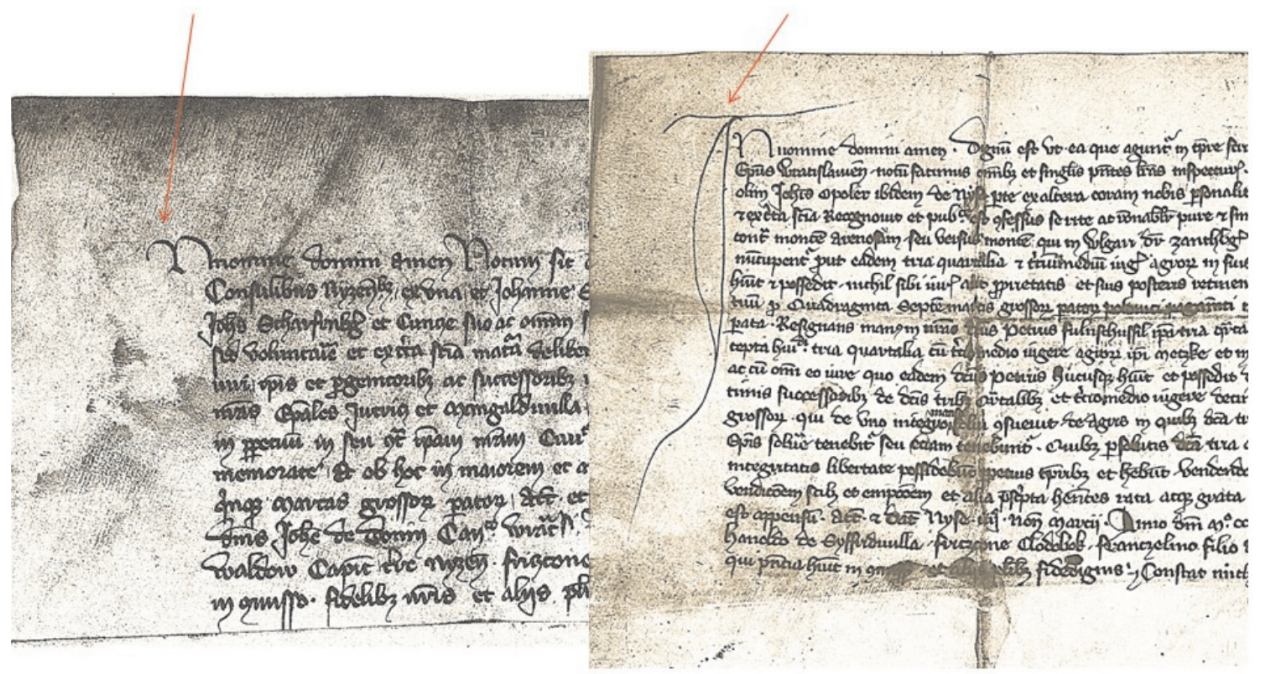

Fot. 12. Dokumenty Przecława, biskupa wrocławskiego:

a) z 17 marca 1351 roku. AP Opole, Akta miasta Nysy, nr 20;

b) z 4 marca 1351 roku. AP Opole, Akta miasta Nysy, nr 19 


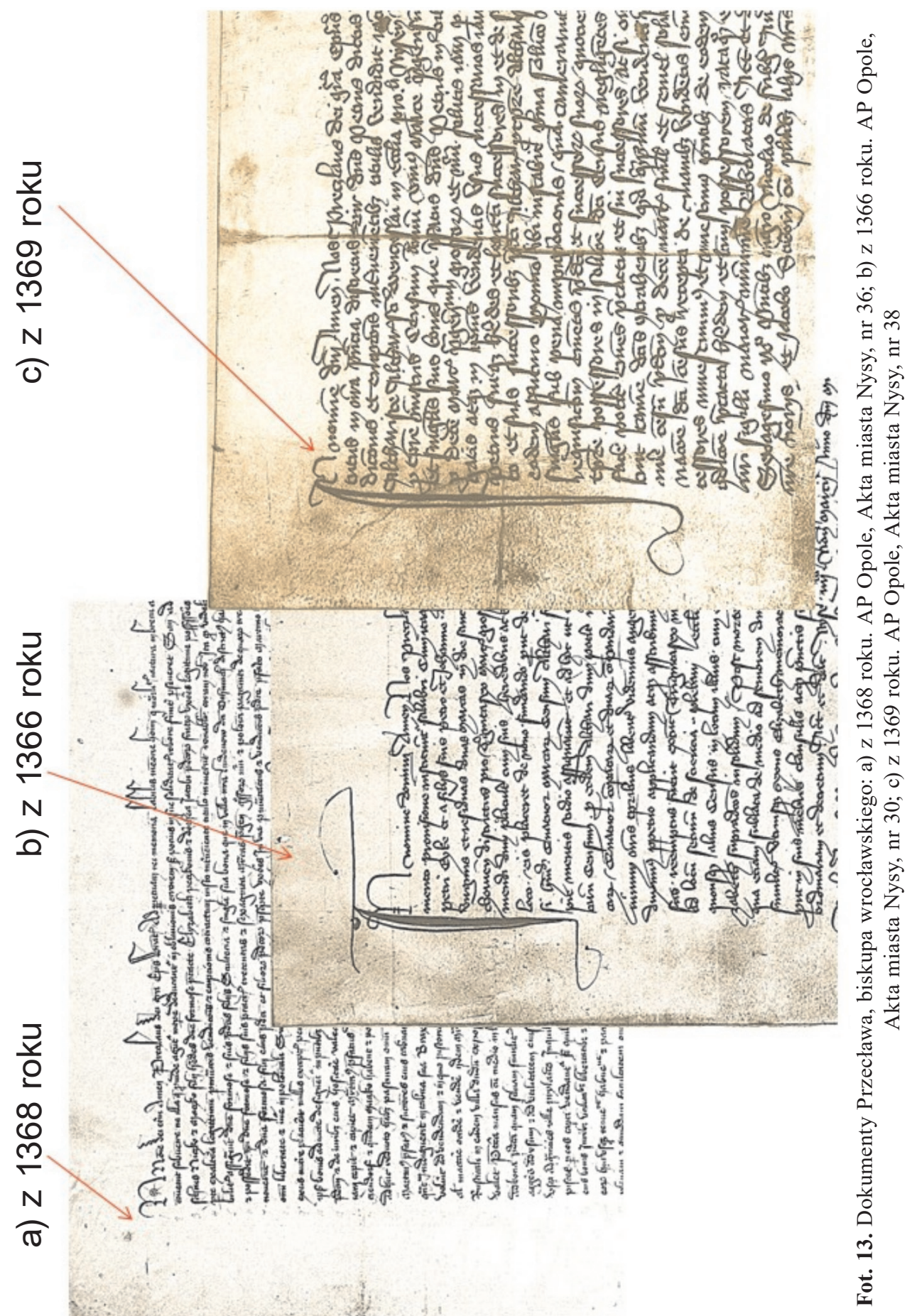




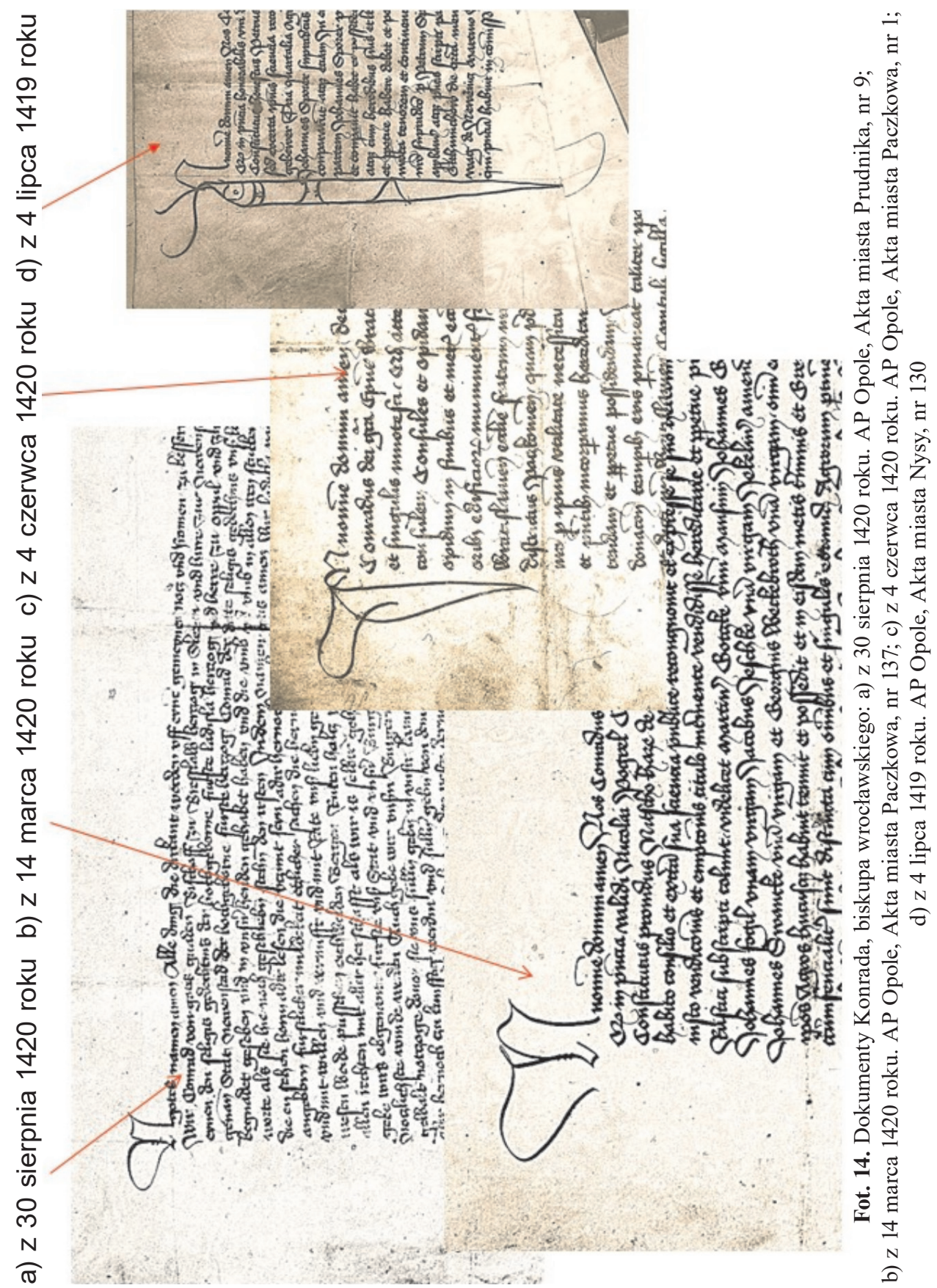


Przedstawione zestawienie, wraz z dołączonym materiałem ilustracyjnym, pozwala poczynić także uwagi na temat pojawiającej się w literaturze koncepcji dotyczącej wkładu iluminatorów w proces powstawania dokumentów, o czym miałyby świadczyć pozostawione dla nich luki w miejscach inicjałów. W wypadku analizowanego materiału koncepcja ta wydaje się mało prawdopodobna. Śląskie kancelarie, nawet te najprężniej działające, były zbyt małe, by zatrudniać w nich dodatkowe, prócz pisarzy, osoby. Szczególnie dobrze widoczne jest to na przykładzie niewielkich i słabo zorganizowanych kancelarii górnośląskich, pośród wytworów których również odnajdujemy dokumenty bez wrysowanych inicjałów (fot. 10). Bez wątpienia można jednak wyraźnie dostrzec, że w procesie wygotowywania dyplomu najpierw spisywano jego treść, pozostawiając miejsce na wrysowanie inicjału. Działo się tak nawet wówczas, gdy dokument nie prezentował się pod względem graficznym szczególnie okazale. Dość wyraźnie wskazuje na to wzajemne krzyżowanie się linii inicjału i tekstu oraz kolejność nanoszenia poszczególnych elementów zapisu ${ }^{62}$ (fot. 13 i 14). Widoczne jest to także $\mathrm{w}$ rozplanowaniu zapisu na karcie, gdy niejednokrotnie można odnieść wrażenie, że inicjał został niejako „,na siłę” wkomponowany przed tekstem (fot. 11). Te zaś inicjały, które wrysowano w dokumenty, zostały wykonane tym samym narzędziem, którym spisywany był cały dyplom ${ }^{63}$ (fot. 14).

Reasumując, na Śląsku dokumenty bez wrysowanych inicjałów pojawiały się w okresie całego średniowiecza, podobnie zresztą jak na terenie Niemiec. Obszar ich występowania obejmował całą dzielnicę. Znajdujemy je więc zarówno w kancelariach reprezentujących bogatszych dolnośląskich wystawców, jak i tych biedniejszych z terenów Górnego Śląska, w dokumentach wystawców reprezentujących różne środowiska społeczne na tym obszarze. Spisywane były one zarówno w języku łacińskim, jak i języku niemieckim. Dotyczyły różnorodnych spraw związanych z przeniesieniem praw własności, nie odróżniając się tym samym od dokumentów inicjały posiadających. Wreszcie, sporządzane były przez tych samych pisarzy, którzy spisywali też dyplomy ukończone ${ }^{64}$. Zastanawia więc, jaki czynnik miał determinujący wpływ na fakt, że jedne dokumenty opuszczały kancelarię w pełni wykończone, inne zaś bez początkowej litery, nie wzbudzając przy tym żadnego dysonansu poznawczego zarówno u wystawcy, jak i przede wszystkim u odbiorcy danego dyplomu. Nasuwa się tu zatem dość samoistnie przypuszczenie, że to właśnie odbiorca miał wpływ na ostateczny wygląd dokumentu oraz prawo decydowania w zakresie jego graficznej formy, co było zapewne podyktowane ponoszonymi przez niego kosztami. Moim zdaniem więc, to odbiorca decydował, jak bogaty i dopracowany ma być inicjał na wystawianym dla niego dokumencie. Niech za przykład potwier-

${ }^{62}$ Widoczne jest to przy znacznym powiększeniu.

${ }^{63}$ I. Pietrzyk: Inicjaty..., s. 97.

${ }^{64}$ Co bardzo dobrze ukazuje prezentowane w niniejszym artykule zestawienie dokumentów. 
dzający tę sugestię posłużą dwa wzmiankowane już dyplomy, których wystawcą był niejaki Piotr Rosslau (fot. 11, punkt 5). Oba zostały wystawione w tym samym dniu, spisane przez tego samego pisarza, ich odbiorca również był ten sam. W jednym z dokumentów wrysowano inicjał prawdopodobnie od razu, w drugim zaś, poświadczającym wyższą wartość transakcji, w założeniu inicjał miał być zapewne bogatszy, wymagający zatem poświęcenia większej ilości czasu na jego wykonanie, a co za tym idzie — i wyższej zapłaty. Stąd prawdopodobnie jego wykonanie zwyczajnie odłożono na później, tym bardziej że, jak wskazują badania, brak inicjału nie powodował żadnego uszczerbku dla mocy prawnej dokumentu. Skala zaś samego zjawiska pozwala także na stwierdzenie, że to nie zaniedbanie czy brak czasu wpływały na pozostawianie dokumentów bez wrysowanych inicjałów. Była to bez wątpienia powszechnie stosowana i akceptowana prawnie praktyka średniowiecznych kancelarii dostrzegających w tym zakresie również własne korzyści. Jak powszechna w skali europejskiej była to praktyka, wskażą — miejmy nadzieję — dalsze badania.

\section{Bibliografia}

\section{Źródla rękopiśmienne}

Archiwum Państwowe w Opolu: Akta miasta Nysy, nr 19, 20, 30, 36, 38, 93, 130; Akta miasta Paczkowa, nr 1, 49, 137, 146, 147; Akta miasta Prudnika, nr 9.

Archiwum Państwowe we Wrocławiu: Rep. 3, sygn. 748a; Rep. 4f, nr 55b, sygn. 13; Rep. 67, nr 159; Rep. 71, nr 5a; Rep. 84, nr 45; Rep. 91, nr 124, 133; Rep. 107, nr 2; Rep. 114, nr 18; Rep. 116, nr 13.

Národní archiv Praha, Archiv České Koruny, inv. č. 118, 124.

Statní okresní archiv Opava, AmOpava, i.č. 2, sign.I/7.

Zemský archiv v Opavě, Jan Spatzier, inv. č. 26.

\section{Źródla drukowane}

Lehns- und Besitzurkunden Schlesiens und seiner einzelnen Fürstenthümer im Mittelalter. Bd. 2. Hrsg. C. Grünhagen, H. Markgraf. Leipzig 1883.

Regesty dokumentów przechowywanych na Górnym Śląsku. T. 1-3. Red. A. Barciak, K. Müller. Wrocław-Opawa-Opole-Katowice 2004-2017.

Schlesisches Urkundenbuch. Bd. 1-6. Hrsg. H. Applet, W. Irgang. Köln-München 1963-1998. Stelmach R.: Katalog średniowiecznych dokumentów przechowywanych w Archiwum Państwowym we Wrocławiu. Wrocław-Racibórz 2014. 


\section{Opracowania}

Andrian-Werburg K. von: Die Fehlende Initiale. „Zeitschrift für bayerische Landesgeschichte“ 1992, Bd. 55.

Antonín R.: Jan Lucemburský a slezská knižata v letech 1327-1329. „Slezský sborník. Acta Silesiaca Opava“ 2010, roč. 108, č. 1-2.

Bar P.: Lenni listiny z let 1271-1348 a integracje slezských vévodů do svazku zemí Koruny české. V: Slezsko — země Koruny české. Historie a kultura 1300-1740. Díl. A. Edd. H. Dánová, J. Klípa, I. Stolárová. Praha 2008.

Geschichte Schlesiens. Von der Urzeit bis zum Jahre 1526. Bd. 1. Hrsg. L. Petry, J.J. Menzel, W. Irgang. Stuttgart 2000.

Hlaváček I.: Zu den graphischen Elementen im böhmischen Urkundenwesen der vorhussitischen Zeit (bis 1419). In: Graphische Symbole in mittelalterlichen Urkunden. Beiträge zur diplomatischen Semiotik. Hrsg. P. Rück. Sigmaringen 1996.

Irgang W.: Schlesien im Mittelalter. In: Schlesien. Geschichte, Kultur und Wirtschaft. Hrsg. W. Irgang, W. Bein, H. Neubach. Köln 1995.

Jurek T.: Zarys dyplomatyki śląskiej w późnym średniowieczu. W: Dyplomatyka staropolska. Red. T. Jurek. Warszawa 2015.

Koczerska M.: Zbigniew Oleśnicki i Kościót krakowski w czasach jego pontyfikatu (14231455). Warszawa 2004.

Książęta i księżne Górnego Śląska. Red. A. Barciak. Katowice 1995.

Pietrzyk I.: Inicjały na czternastowiecznych dokumentach książat opolskich (Bolesława II i Bolesława III). „Średniowiecze Polskie i Powszechne” 2017, T. 9 (13).

Sułkowska-Kurasiowa I.: Inicjaty na średniowiecznych dokumentach monarszych $w$ Polsce (do 1444 r.). W: Kultura średniowieczna i staropolska. Studia ofiarowane Aleksandrowi Gieysztorowi w pięćdziesięciolecie pracy naukowej. Warszawa 1991.

Wójcik M.L.: Dokumenty i kancelarie książat opolsko-raciborskich do początków XIV wieku. Wrocław 1999.

Żerelik R.: Kancelaria biskupów wrocławskich do 1301 roku. Wrocław 1991.

\section{Iwona Pietrzyk}

\section{Negligence, Lack of Time, or the Common Practice of Medieval Chancelleries? On the Missing Initials in Silesian Documents}

Summary

Despite the fact that it was common practice for medieval law chancelleries to put into legal circulation documents with missing initials, this phenomenon has been neglected by research. Iwona Pietrzyk's article partially fills this gap by examining a collection of medieval documents issued by Silesian chancelleries. Her choice of this material has been determined by the specificity of Silesia itself, with its numerous territorial authorities subject to changes over time, its economic, ethnic and cultural diversity, and its rich diplomatic material. Pietrzyk's research indicates that documents without initials were in circulation in Silesia throughout the Middle Ages. They were issued by various chancelleries, both lay and ecclesiastical, and they 
came from both the issuer and the recipient. Pietrzyk argues that we are dealing here with the common practice of medieval chancelleries, rather than with an individual oversight or negligence of a clerk. On the basis of her analysis, Pietrzyk concludes that the decision to leave an empty space in place of an initial was not that of the issuer of the document or the chancelleries staff, but that of the recipient, who, bearing the costs of drawing up the diploma, had the right to decide on its more or less elaborate graphic form. Also, it was for the recipient to decide to leave an empty space in order to fill the gap in the future with an initial appropriate to the rank of the document.

Keywords: missing initials, documents without initials, Silesian documents, diplomacy, the Middle Ages

Iwona Pietrzyk

\section{Vernachlässigung, Zeitmangel oder gängige Praxis der mittelalterlichen Kanzleien?} Über fehlende Initialen in schlesischen Dokumenten

Zusammenfassung

Obwohl es in mittelalterlichen Kanzleien gängige Praxis war, Urkunden mit fehlenden Initialen in den Rechtsverkehr zu bringen, ist dieses Phänomen immer noch wenig erforscht. Ziel dieses Artikels ist es, diese Forschungslücke teilweise zu schließen. Analysiert wurde darin eine Sammlung von mittelalterlichen Dokumenten schlesischer Aussteller. Die Wahl des Materials wurde durch den spezifischen Charakter Schlesiens beeinflusst - mit einer Vielzahl von Gebietsherrschaften, die im Laufe der Zeit territorialen Veränderungen unterlagen, mit dessen wirtschaftlicher, ethnischer und kultureller Vielfalt und einem reichen diplomatischen Material. Die durchgeführten Untersuchungen zeigen, dass Urkunden ohne Initialen in ganz Schlesien während des gesamten Mittelalters auftauchten. Sie erschienen bei verschiedenen Gruppen von Ausstellern, sowohl säkularen als auch kirchlichen, in Dokumenten, die aus dem Kreis des Ausstellers, aber auch des Empfängers stammten. Daraus lässt sich schließen, dass es sich dabei um eine gängige Praxis der mittelalterlichen Kanzleien handelt und nicht um ein individuelles Versehen bzw. die Nachlässigkeit eines Kanzleibeamten. Auf der Grundlage der durchgeführten Analysen kann auch der Schluss gezogen werden, dass nicht der Aussteller des Dokuments oder das Kanzleipersonal darüber entschied, die Initialen auszulassen, sondern der Empfänger selbst, der die Kosten für die Erstellung des Diploms trug und das Recht hatte, über dessen mehr oder weniger reiche grafische Form zu entscheiden. Er durfte auch beschließen, das Feld leer zu lassen, um in Zukunft die Lücke mit einer dem Rang des Dokuments entsprechenden Initiale zu füllen.

Schlüsselwörter: fehlende Initialen, Urkunden ohne Initialen, schlesische Urkunden, Diplomatik, Mittelalter 